\title{
Appendicular Abscess in the Service of General Surgery at the Teaching Hospital Gabriel Toure, Bamako, Mali
}

\author{
Madiassa Konate*, Traore Amadou, Coulibaly Yacaria, Dembele Bakary Tiéntigui, \\ Karembe Boubacar, Keita Soumaila, Amadou Issa, Mangane Moustaphissa, \\ Diop Thierno Madani, Almeimoune Abdoul Hamidou, Togo Adégné Pierre, \\ Kante Lassana, Traore Alhassane, Maiga Amadou, Bah Amadou, \\ Sidibe Boubacaryoro, Diamoutene Kolo, Tolo Maimouna, Samake Moussa, \\ Mounimezié Diarra, Diakite Ibrahim, Diallo Gangaly
}

FMOS, Bamako, Mali

Email: *konate8@gmail.com

How to cite this paper: Konate, M., Amadou, T., Yacaria, C., Tiéntigui, D.B., Boubacar, K., Soumaila, K., Issa, A., Moustaphissa, M., Madani, D.T., Hamidou, A.A., Pierre, T.A., Lassana, K., Alhassane, T., Amadou, M., Amadou, B., Boubacaryoro, S., Kolo, D., Maimouna, T., Moussa, S., Diarra, M., Ibrahim, D. and Gangaly, D. (2018) Appendicular Abscess in the Service of General Surgery at the Teaching Hospital Gabriel Toure, Bamako, Mali. Surgical Science, 9, 281-285

https://doi.org/10.4236/ss.2018.98033

Received: July 13, 2018

Accepted: August 27, 2018

Published: August 30, 2018

Copyright (ㅇ 2018 by authors and Scientific Research Publishing Inc. This work is licensed under the Creative Commons Attribution International License (CC BY 4.0).

http://creativecommons.org/licenses/by/4.0/

\section{cc) (i) Open Access}

\begin{abstract}
Objectives: To determine hospital frequency and to write the diagnostic and therapeutic aspects of appendicular abscess in adults in the General Surgery Department of teaching Hospital Gabriel Touré from 2005 to 2017. Material and Methods: This was a retrospective study conducted from January 1, 2005 to December 31, 2017 in the General Surgery Department of Gabriel Touré University Hospital in all patients with appendicular abscess. Results: In 13 years, 1420 cases of acute appendicitis have been reported, including 105 cases of appendicular abscess (7.4\%). Mean age of the patients was 32 years with extremes of 16 years and 70 years. Abdominal pain and fever were present in all patients. Pain sat in the right iliac fossa in $73.3 \%$ and was epigastric in $11.4 \%$. In almost all cases abdominal defense was present (97.1\%). There was generalized abdominal contracture in $2.8 \%$ of cases. Average duration of evolution was 27 days with extremes of 1 day and 60 days. Ultrasonography was performed in $42.6 \%$ of cases and found peri-appendicular effusion in 29 cases (27.6\%). 90 incisions were made by incision of Mac Burney, 8 by median umbilical, 7 by midline above and below umbilical. The amount of fluid aspirated was greater than $100 \mathrm{cc}$ in 47 patients. We performed an appendectomy with appendicular stump burying followed by washing plus drainage of the abdominal cavity in 65 patients. Morbidity rate was $14.3 \%$. No deaths were recorded. Average duration of hospitalization was 6.5 days with extremes of 2 days and 26 days.
\end{abstract}




\section{Keywords}

Appendicular Abscess, Adult, Appendectomy, Mali

\section{Introduction}

Appendicular abscess represents one of the evolutionary modes which follow the perforation of the appendix in which diffusion of infection is "contained" by the large epiploon and the slender loops resulting in the constitution of a real located abscess of the large peritoneal cavity [1]. It is the initial clinical picture found in approximately $50 \%$ of cases in adults [1] and constitutes a medico-surgical emergency. Appendicular abscess accounts for $10 \%$ of adult acute appendicitis in Africa [2]. Diagnosis is clinical, in case of doubt ultrasound allows to make it. Treatment of abscess is emergency drainage by radiological or surgical route combined with antibiotic therapy [3]. The benefits of endoscopic surgery remain controversial so far compared to the open way but currently laparoscopic surgery has become the gold standard in digestive surgery. In the absence of early surgical drainage, the abscess progresses spontaneously to appendicular peritonitis [4].

Given the high frequency and lack of more specific study on appendicular abscesses in adults in the department, this work has been initiated.

\section{Materiel and Methods}

This was a prospective, 13-year study from January 1, 2005 to December 31, 2017 covering all patients operated for appendicular abscess over 15 years of age in the General Surgery Department of the teaching hospital GABRIEL Toure.

All patients operated for appendicular abscess confirmed perioperatively and at pathological examination were included. Data were collected from medical and operational records. Data entry and analysis were done on Word 2007 Epi-info SPSS software. The statistical tests used were $\mathrm{Chi}^{2}$ with a statistically significant difference for the $\mathrm{p}<0.05$ values.

\section{Results}

We collected 105 cases of appendicular abscess in 13 years. During the same period 7820 patients were operated in emergency among which 1420 cases of appendicitis (7.4\%). These accounted for $0.4 \%$ of hospitalizations.

Patients' average age was 32 years old with extremes of 16 and 70 years old.

Sex ratio was 2.75. 90 patients (85.7\%) have been received in emergency consultation. Abdominal pain and fever were present in all patients.

Pain was located in the right iliac fossa in 77 patients (73.33\%) and was epigastric in 12 patients (11.42\%). Abdominal defense was present in 102 patients (97.14\%). There was generalized abdominal contracture in 3 cases $(2.85 \%)$ on resume Table 1. 
Table 1. Pain location at the beginning.

\begin{tabular}{ccc}
\hline Location & $\mathbf{n}$ & $\%$ \\
\hline Right iliac fossa & 77 & 73.3 \\
epigastrium & 12 & 11.4 \\
Peri-ombilical & 7 & 6.6 \\
Hypogastric & 3 & 2.8 \\
Pelvic & 3 & 2.8 \\
Diffuse & 3 & 2.8 \\
Total & 105 & 100 \\
\hline
\end{tabular}

The average duration of evolution was 27 days with extremes of 1 day and 60 days. Ultrasound was performed in 46 patients (42.6\%) and found peri-appendicular effusion in 29 cases.

90 incisions were made by incision of Mac Burney, 8 by median umbilical, 7 by midline above and below umbilical. The amount of fluid aspirated was greater than $100 \mathrm{cc}$ in 47 patients (44.8\%). The resume on Table 2.

Therapeutic gestures made are summarized in Table 3.

We performed an appendectomy with appendicular stump burying followed by washing plus drainage of the abdominal cavity in 65 patients $(58.1 \%)$, an simple appendectomy in 24 cases (22.9\%), appendectomy with burying without drainage in 6 patients (5.7\%) and simple drainage was performed in 10 cases (9.5\%).

We noted a morbidity rate in 15 cases (14.3\%). No deaths were recorded. Our average hospital stay was 6.54 days with extremes of 2 and 26 days.

\section{Discussion}

Appendicular abscess is a significant complication of acute appendicitis. It accounts for $10 \%$ of acute appendicitis in adults in Africa. On the other hand, it constitutes the initial clinical picture in 50\% in the young person. It accounted for $7.4 \%$ of appendicitis in our series. The statistically significant difference between frequency in Nigeria and ours could be influenced by early management of appendicitis [3].

Appendicitis is especially pathology of the young adult like appendicular abscess, but it is rare in old man [4].

According to the literature, age is not a risk factor. Average age of 32 years in our study does not differ from that of the studies [3] [4].

Male was the most represented in our study as in all authors [3] [4] with sex ratios ranging from 1.28 to 2.75 . Sex does not represent a risk factor in the literature [5].

The consultation time is a determining factor in the prognosis of appendicitis [6]. Appendicitis can also progress at low levels due to diagnostic difficulties with the formation of an appendicular abscess [7] [8]. Fever is constant and is above $38.5^{\circ} \mathrm{C}$ [9]. We found it in all patients in our series. 
Table 2. The amount of sucked pus.

\begin{tabular}{ccc}
\hline Amount of pus & $\mathbf{n}$ & $\%$ \\
\hline$<20 c c$ & 22 & 20.9 \\
$30-50 c c$ & 24 & 22.8 \\
$60-90 c c$ & 12 & 11.4 \\
$>100 c c$ & 47 & 44.8 \\
Total & 105 & 100 \\
\hline
\end{tabular}

Table 3. The postoperative course according to the actions performed.

\begin{tabular}{ccccc}
\hline & \multicolumn{3}{c}{ Outcomes } \\
\cline { 2 - 4 } Gestures made & Simples & $\begin{array}{c}\text { Parietal } \\
\text { suppuration }\end{array}$ & $\begin{array}{c}\text { Suppuration }+ \\
\text { postoperative } \\
\text { Occlusion }\end{array}$ & Total \\
\hline $\begin{array}{c}\text { Appendicectomy + burying }+ \\
\text { drainage }\end{array}$ & 56 & 8 & 1 & 65 \\
$\begin{array}{c}\text { Appendicectomy + burying } \\
\text { without drainage }\end{array}$ & 5 & 1 & 0 & 6 \\
$\begin{array}{c}\text { Appendicectomy + drainage } \\
\text { Drainage }\end{array}$ & 20 & 4 & 0 & 24 \\
Total & 9 & 1 & 0 & 10 \\
\hline
\end{tabular}

In the literature appendicular abscess is characterized by the existence of violent pain [10] [11]. It was noted in $95.23 \%$ of the cases.

Digestive disorders (nausea, vomiting, diarrhea or constipation) are present in all series. Right lateral pain at rectal examination is found.

Ultrasound with a sensitivity of $80 \%$ for diagnosis can provide additional information on the pathological stage as well as the topography and is useful in case of difficult or doubtful diagnosis [12]. In our study, 46 patients (43.80\%) underwent ultrasonography. Diagnosis of appendicular abscess was made in twenty-nine patients (63.04\%). This result is different from those of the Italian and Korean series [13] [14]. Any abscess diagnosed must be operated as soon as possible, in order to eliminate the infectious focus to prevent the spread of infection in the peritoneal cavity [15] [16]. Laparoscopic approach should be favored today according to the literature. There is no difference in terms of morbid and mortality between the two pathways of burying the appendicular stump or not. However, a difference was found between syndrome of the fifth day in the series where there is no burying [6] [8] [10] [12] [16].

\section{Conclusion}

Appendicular abscess is a common surgical emergency. It follows acute appendicitis whose diagnosis is delayed by non-specific treatments in our country appendectomy plus drainage was the technique used. 


\section{Conflicts of Interest}

The authors declare no conflicts of interest regarding the publication of this paper.

\section{References}

[1] Garcia, S., Heloury Y. and Plattner, V. (1990) Appendicite aigue et péritonite: Chirurgiedigestive de l'enfant. Ed.Douin, Paris, 6/6.

[2] Guifo, M.L., Takongmo, S. and Fokou, M. (2010) Abcès appendiculaires: analyse de 19 cas traités au Centre Hospitalier et Universitaire de Yaoundé et déductions pratiques. Pan African Medical Journal, 5, 36-39.

[3] Pie, I.S., Okafor, M.D., Jideofor, C., Orakwe, M.B.B.Ch., Gabriel, U. and Chianakwana M.B.B.Ch. (2003) Gestion des masses appendiculaires dans un hôpital périphérique au Nigeria. World Journal of Surgery, 27, 800-803.

[4] Hussain, et al. (2011) Gestion des abcès appendiculaires : département de Chirurgie. King Saud Médical City, Riyad, au Royaume d'Arabie Saoudite, 4.

[5] Juricic, M. (2008-2009) Pathologie digestive médico-chirurgicale. Appendicite aigue de l'enfant. Université Paul Sebatier-Toulouse, chap. 5-urgences 2008-2009, 304-309.

[6] Reinhard, B. (2006) Laparoscopic Surgery-15 Years after Clinical Introduction. World Journal of Surgery, 30, 1190-1203. https://doi.org/10.1007/s00268-005-0644-2

[7] Frazee, R.C., Roberts, J.W., Symmonds, R.E., Snyder, S.K., Hendricks, J.C., Smith III, R.W., Custer, M.D. and Harrison, J.B. (1994) A Prospective Randomized Trial Comparing Open versus Laparoscopic Appendectomy. Annals of Surgery, 219, 725-728. https://doi.org/10.1097/00000658-199406000-00017

[8] Plattner, V., Raffaitin, Ph., Miraille, E., et al. (1997) Appendicites compliquées de l'enfant : laparoscopie ou Mc Burney? Annales De Chirurgie, 51, 990-994.

[9] Appendicitedel'enfantetdel'adulte (2008) Conference de Consensus Appendicite. Hépato-gastroentérologie et chirurgie digestive, 43.1.

[10] Rohr, S., et al. (1999) Appendicite aiguë EMC (Paris). Gastro entérologie 1999: 9-066A10, 11.

[11] Leguerrier, A. (1980) Nouveaux dossiers d'anatomie. Editions scientifiques et juridiques 1980, 801, 93-106.

[12] Condonre, et al. (1991) Text Book of Surgery. WB Saunders, Philadelphia, 15-32.

[13] Delattre, J.F. (1997) Appendicite aiguë et ses complications diagnostiques, traitement. Impact Internat, 356.

[14] Segolph, et al. (1996) Appareil digestif DCEM, 2ème année Service de polycopie des étudiants, des professeurs de santé de Caen. Edition 1996, 97: 261-274.

[15] Hale, D.A., et al. (1997) Appendectomy. A Contempory Appraisal. Annals of Surgery, 225, 252-261. https://doi.org/10.1097/00000658-199703000-00003

[16] Le Mandat, D.A. (2008) Appendicite aigue de l'enfant (et de l'adulte) Version 2008, 8. 